\title{
Intracerebral Hematoma Following Lumboperitoneal Shunt Insertion: A Rare Case Report
}

\author{
Lumboperitoneal Şant Takılmasın Takiben Gelişen Intraserebral \\ Hematom: Nadir Bir Olgu Sunumu
}

\author{
Erhan TURKOGLU ${ }^{1}$, Burak KAZANCI ${ }^{1}$, Ergun KARAVELIOGLU ${ }^{1}$, Metin SANLI ${ }^{1}$, Burcu KAZANCI ${ }^{2}$, \\ Zeki SEKERCI ${ }^{1}$ \\ 1Ministry of Health Yildirim Beyazit Diskapi Education and Research Hospital, 1. Neurosurgery Clinic, Ankara, Turkey \\ 2Ministry of Health Ulucanlar Eye Education and Research Hospital, Eye Clinic, Ankara, Turkey
}

Correspondence address: Erhan TURKOGLU / E-mail: drmet122@yahoo.com

\begin{abstract}
Lumboperitoneal shunting is widely used for the surgical management of pseudotumor cerebri and other pathologies such as communicating hydrocephalus. Although it is a safe method, it could be associated with complications including subarachnoid hemorrhage, subdural and rarely intracerebral hematoma. A 44-year-old female applied to our clinic with complaints of severe headache, retroorbital pain and blurred vision. Lumbar puncture demonstrated cerebrospinal fluid opening pressure of $\mathrm{cmH} 2 \mathrm{O}$. A non-programmable lumboperitoneal shunt with two distal slit valves was inserted due to pseudotumor cerebri. She deteriorated shortly after surgery. Immediate cranial computed tomography scan revealed a right parietal intracerebral hematoma. Development of intracerebral hematoma following lumboperitoneal shunt is a rare complication. We discuss this rare event accompanied by the literature.
\end{abstract}

KEYWORDS: Complication, Intracerebral hematoma, Lumboperitoneal shunt, Pseudotumor cerebri

öz

Lumboperitoneal şant, pseudotümor serebri ve kominikan hidrosefali gibi diğer bazı patolojilerin cerrahi tedavisinde oldukça yaygın kullanılmaktadır. Güvenilir bir metod olmasına karşın, subaraknoid hemoraji, subdural ya da nadiren intreserebral hematom gibi komplikasyonlarla ilişkili olabilir. 44 yaşında bayan hasta kliniğimize ciddi başağrısı, retroorbital ağrı ve bulanık görme yakınmalarıyla başvurdu. Lomber ponksiyon ile beyin omurilik sıvısı açılış basıncı $28 \mathrm{cmH} 2 \mathrm{O}$ idi. İki adet distal slit valvi olan programlanamayan şant pseudotümör serebri tanısıyla hastaya takıldı. Cerrahiden kısa bir süre sonra hastanın kliniği bozuldu. Acil bilgisayarlı beyin tomografisi sağ paryetal intraserebral hematom gösterdi. Nadir gözlenen bu olay literatür eşliğinde tartışılmıştır.

ANAHTAR SÖZCÜKLER: Intraserebral hematom, Lumboperitoneal şant, Komplikasyon, Pseudotumor serebri

\section{INTRODUCTION}

Lumboperitoneal shunting (LP) is widely used for the surgical management of pseudotumor cerebri (PTC) and other selected pathologies such as communicating hydrocephalus, cerebrospinal fluid (CSF) fistula and normal pressure hydrocephalus. Use of this device is often restricted by its associated complications, e.g. infection, tonsillar herniation, arachnoiditis and it needs revision frequently $(5,8,11,12)$. LP shunts also have complications such as shunt migration, venous sinus thrombosis, subarachnoid hemorrhage, subdural and intracerebral hematoma $(3,4,9,10,12)$. We present a case of intracerebral hematoma after LP shunt insertion, which resulted in rapid deterioration and coma shortly after surgery. Development of intracerebral hematoma following LP shunt is a quite rare complication and only one case has been reported in the literature (13).

In the present case, we present a presumptive biomechanism of intracerebral hematoma due to LP shunt insertion.

\section{CASE REPORT}

A 44-year-old female was admitted to our clinic with complaints of severe headache, retroorbital pain and blurred vision. Her headache got worse over the next 3 days. She did not have a remarkable history nor used any drugs such as steroids, oral contraceptives, tetracycline, nitrofurantoin or vitamins.

Her physical examination was normal and her body mass index was 36. Neurological examination was normal but ophthalmological examination by fundoscopy revealed bilateral papilledema with tortuous vessels. Ophthalmology consultation ruled out other causes of papilledema. Lumbar puncture demonstrated that the CSF opening pressure was $28 \mathrm{cmH}_{2} \mathrm{O}$. Laboratory evaluations of blood and CSF were within normal limits and pituitary function was also normal. Brain magnetic resonance imaging (MRI) and magnetic resonance venography revealed normal parenchymal, orbital findings and no dural sinus thrombosis, respectively (Figure 
1). Sellar MRI demonstrated partial empty sella, and normal optic nerves and optic chiasm.

The empty sella was a corroborative factor and no other causative pathology for increased intracranial pressure could be found. She had been started on acetazolamide $(3 \times 250$ $\mathrm{mg}$, p.o) and furosemide (40 mg $2 \times 1$, p.o) for four weeks. Moreover, serial LPs were done but her headache and visual symptoms did not improve. Therefore, a non-programmable LP shunt with two distal slit valves (Phoenix Biomedical Corp, Valley Forge, USA) was inserted. She deteriorated shortly after surgery and became comatose. Glasgow Coma Scale (GCS) score was $6 / 15$. Immediate CT scan revealed a right parietal intracerebral hematoma associated with minimal midline shift. There was no hematoma in the sylvian fissure and no subarachnoid blood in the cisterns (Figure 2).

The patient was intubated and transferred to the intensive care unit. She had a stormy course consisting of chest infection, prolonged intubation and tracheostomy. Therefore, cerebral digital subtraction angiogram, MR angiography or 3DCTangiography and control CT scan could not be performed to exclude an aneurysm as the cause of hematoma. She died nine days after surgery because of chest infection.

\section{DISCUSSION}

Pseudotumor cerebri is a syndrome characterized by increased intracranial pressure without hydrocephalus or mass lesion and with normal CSF composition. The maximum available medical treatment, such as steroids, acetozolamide, and serial lumbar punctures should be administered before undertaking a shunt placement as a first line therapy. In addition, the relationship between PTC and obesity is well recognized and weight loss can result in resolution of symptoms $(2,10)$. The combination of empty sella syndrome (ESS) and benign intracranial hypertension (BIH) has been noted previously (6). The causal relationship between the ESS and the BIH can be explained by two mechanisms. Raised intracranial pressure could produce a herniation of the subarachnoid cistern into the sella turcica, if the diaphragma sella is incomplete. Alternatively, an infarction of a pituitary adenoma could result in both an ESS and cerebrospinal fluid flow obstruction, which could lead to BIH (6).

LP shunts have been widely used in the surgical management of PTC that are unresponsive to medical management $(2,5,7,8,12,13)$. The major indications for LP shunts are intractable headache (67\%) and progressive optic neuropathy (52\%). Lumboperitoneal shunting can relieve headache, papilledema and can reverse and/or prevent visual loss (2). Ventriculoperitoneal (VP) shunts can also be used instead of LP shunts, but catheterization of the slit ventricles is challenging and could lead to parenchymal injury (such as cortical venous injury or hemorrhage) and resulting epilepsy. LP shunts are also reported to be associated with a lower complication rate than VP shunts in treatment of PTC $(1,7)$. Although placement of a LP shunt has been shown to be an effective and relatively safe procedure, a variety of complications associated with

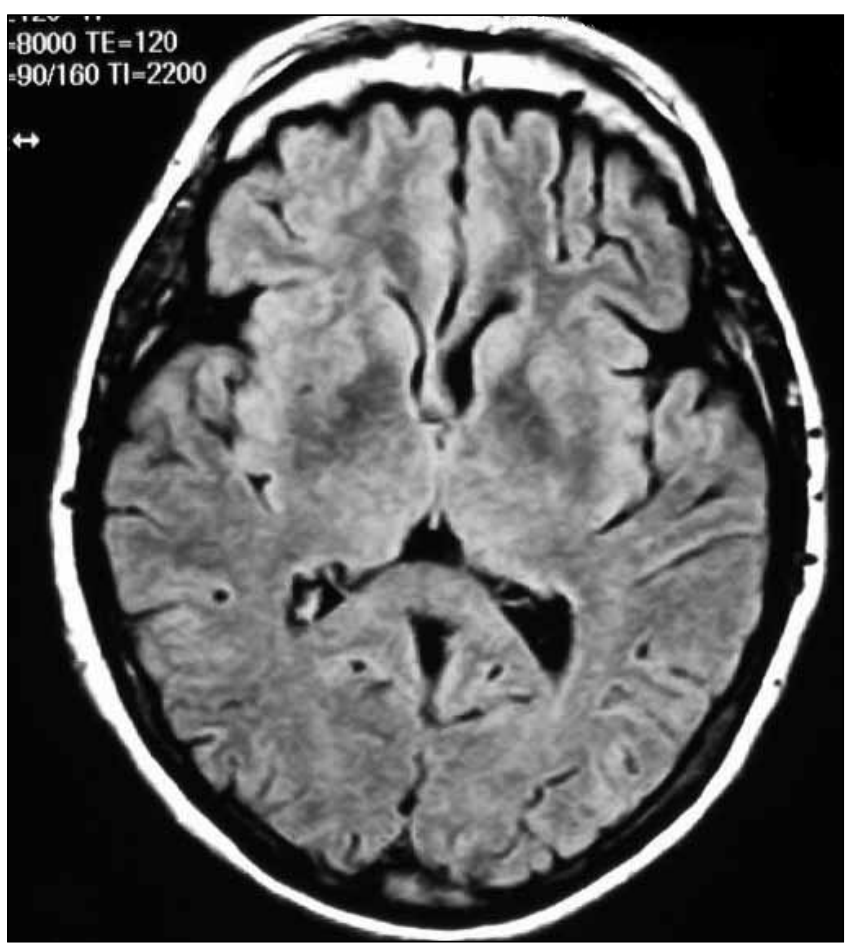

Figure 1: Preoperative T1-weighted axial cranial MRI revealed normal findings except minimal ventricular asymmetry and cortical atrophy.

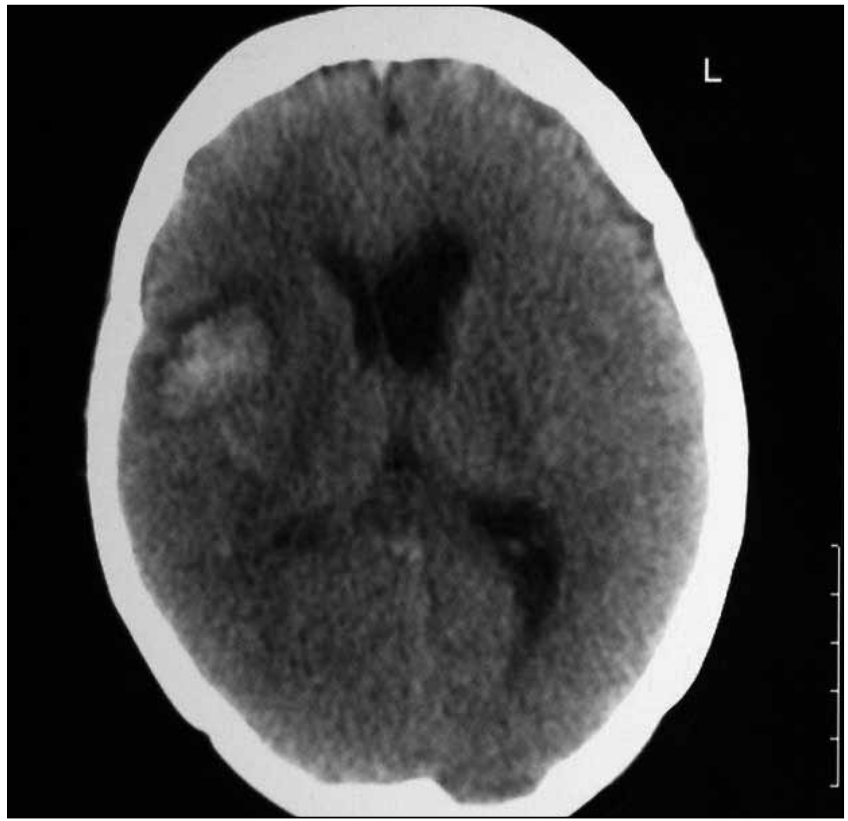

Figure 2: Postoperative cranial CT without contrast agent showing the right parietal hematoma with moderate mass effect. 
LP shunt have been reported in the literature; these include malfunction requiring revision, infection, and migration or fracture of catheter $(1,5,7,10)$. Some rare complications have also been reported, including radiculopathy, foraminal migration of shunt, tonsillar herniation, spinal deformities, subarachnoid hemorrhage and acute subdural hematoma $(4,9,12,13)$. Development of intracerebral hematoma following LP shunt is a quite rare complication and only one case has been reported in the literature (13). The potential pathogenesis is overdrainage, but lack of any subdural effusion or blood argues against this possibility. Lumbar CSF drainage may result in a reduction of CSF volume with a related lowering in intracranial pressure. This may eventually increase the transmural pressure gradient of the vessels, leading to a secondary wall stress rupture. Overdrainage of the CSF during the operation may lead to intracerebral hematoma. We did not allow overdrainage by clamping the catheter tip. Therefore, the hematoma in this patient must be related to the shunt drainage itself.

In conclusion, although intracerebral hematoma following an LP shunt procedure is not common, this complication should be remembered when neurological deterioration occurs after LP shunt placement.

\section{REFERENCES}

1. Aoki N: Lumboperitoneal shunt. Clinical applications, complications, and comparison with ventriculoperitoneal shunt. Neurosurgery 26: 998-1003, 1990

2. Brazis PW : Clinical review. The surgical treatment of idiopathic pseudotumour cerebri (idiopathic intracranial hypertension). Cephalalgia 28:1361-1373, 2008

3. Burgett RA, Purin VA, Kawasaki A: Lumboperitoneal shunting in pseudotumour cerebri. Neurology 49: 734-739, 1997
4. Castillo L, Bermejo PE, Zabala JA: Unusual complications of the lumboperitoneal shunt as treatment of benign intracranial hypertension 23:192-196, 2008

5. Chumas PD, Kulkarni AV, Drake JM, Hoffman HJ, Humphreys RP, Rutka JT: Lumboperitoneal shunting. A retrospective study in pediatric population. Neurosurgery 32: 376-383, 1993

6. De Vries - Knoppert WA: Primary empty sella syndrome and benign intracranial hypertension. Doc Ophthalmol 15: 319-325, 1986

7. Duther R, Nuti C, Motuo-Fotso MJ, Beauchesne P, Brunon J: Complications of lumboperitoneal shunts. A retrospective study of series of 195 patients (214 procedures). Neurochirurgie 42: 83-89, 1996

8. Johnston J, Besser M, Morgan MK: Cerebrospinal fluid diversion in the treatment of benign intracranial hypertension. J Neurosurg 69: 195-202, 1988

9. Kamiryo T, Hamada J, Fuwa I, Ushio Y: Acute subdural hematoma after lumboperitoneal shunt placement in patients with normal pressure hydrocephalus Neurol Med Chir (Tokyo) 43: 197-200, 2003

10. Karabatsou K, Quigley G, Buxton N, Foy P, Mallucci C: Lumboperitoneal shunts: Are the complications acceptable? Acta Neurochir (Wien) 146: 1193-1197, 2004

11. Rosenberg ML, Corbett JJ, Goodwin J, Sergott R, Savino P, Schatz $\mathrm{N}$ : Cerebrospinal fluid diversion procedures in pseudotumor cerebri. Neurology 43: 1071-1072, 1993

12. Solaroglu I, Okutan O, Beskonakli E: Foraminal migration of a lumboperitoneal shunt catheter tip. J Clin Neurosci 12: 956-968, 2005

13. Suri A, Pandey $P$, Mehta VS: Subarachnoid hemorrhage and intracerebral hematoma following lumboperitoneal shunt for pseudotumor cerebri: A rare complication. Neurol India 50: 508-510, 2002 